\title{
A FEMINIST STYLISTICS ANALYSIS IN RUPI KAUR'S THE SUN AND HER FLOWERS
}

\author{
Saskia Febiola Siregar, Eddy Setia, Siamir Marulafau \\ University of Sumatera Utara (USU), Medan, Indonesia \\ E-mail: saskiafebiola763@gmail.com
}

\begin{abstract}
This research was aimed at analyzing linguistic stylistics describing how women and men presented in texts by applying a feminist approach, i.e. feminist stylistics. This research focuses not only on stylistics analysis that considers linguistic structure and how it affects society, but also on how the position of women as actors, as well as the position of ideas or events presented in the text. This research used a qualitative method. The words, phrases or sentences, and discourses reflecting gender-specific in the novel become the data of the research. The researchers use Mills' feminist stylistics theory to analyze the data. In this study, there are several tendencies of women or men associated with the text. In a collection of poems, it is often found several italics at the bottom, and it is to emphasize the topic of the poem concerned. This research shows that Rupi Kaur, as the author, seems to want readers to understand his poetry as much as what he wrote and wanted. In addition, this study found that gender-specific terms are mostly used to refer primarily to female gender.
\end{abstract}

Keywords: Feminist Stylistics, Gender-Specific, Word, Phrase, Sentence, Discourse.

\section{Introduction}

Literary stylistics and linguistic stylistics are different. Literary stylistics focuses primarily on providing "the basis for fuller understanding, appreciation and interpretation of avowedly literary and author-centred texts". On the other hand, "the purest form of stylistics, in that its practitioners attempt to derive from the study of style and language a refinement of models for the analysis of language and thus to contribute to the development of linguistic theory" Carter and Simpson (1989: 3-4). Riffaterre (1971: 30) mentions style as an expressive or emotive language element that is added to the neutral presentation of the message itself. Accordingly, style referred to the using of language elements - words, phrases, sentences, etc. - which contain expressive and emotive values.

In The Sun and Her Flowers, Kaur graciously voiced the beauty of women, and the importance of such recognition; separating ideas about powerful women from various racial, cultural or ethnic differences in the world. Kaur, who lived in Canada, originally raised in India as an immigrant. She has experienced the usual separation from maledominated Caucasian society, and utilized the struggles to advocate for women and young girls to recognize their own strengths, while projecting the idea of equality for all. Instead of bringing other women down, she imagined a world where women use their power to build each other up. Supporting feminism also means encouraging women to think big and never let socially accepted norms stop their imagination. 


\section{Literature Review}

\subsection{Linguistics Determinism}

According to Vetterling-Braggin (1981:3) as quoted in Mills (2005: 62) a widely accepted definition of sexist language is the statements use constitute, promote or exploit an unfair or irrelevant or impolite differences between genders. Need to be extended world perception, and to understand the true role of sexes 'natural' influenced by the language we use. We need to consider whether language is fair 'contemplate' the world, or whether a case is made for the language that influences the way we see the world.

Mills (2005: 63) defines the linguistic theory determinism, that "differences in the structure of language actually determine different views that people have about the world". It is recommended that the language of a culture shapes the way its speakers see the world. As the example, how people name the world differently, emphasizing different aspects, depending on what is relevant to their lifestyle. Along these lines, the determinism of linguistic arguing that language distorts our view of the world. Besides argument states that our systems of thought are influenced by the language of our community, so that our idea of 'reality' is limited by the linguistic forms available as members of that community. The argument is about how language affects our understanding of the world important to feminists for many reasons. Some feminists accept language certainty arguments at each stage for linguistic reform, because they claim that the circulation of these meanings is to realize and strengthen sexism in society. The terms 'chairperson' and 'spokesperson', they both labels were still used in the media when talking about a male, and gender neutral terms are used when talking about a woman.

\subsection{Feminism}

The term 'feminism' began in US and Europe in the late century of $19^{\text {th }}$ as a political parties that fight for women's suffrage and defend other rights in society. In the 1960s and 1970s, feminism grew stronger, voices, and active trips led by various donors from the West. Today, feminism has become an interesting intellectual thought various aspects of learning, including learning about language and literature. Gibbons (1999: 4) sets out the idea and its aims feminism as well as practice, a philosophy that challenges social arrangements regarding women's and men's inherent value, status, position, roles and opportunities. There is no single unifying body of feminist thinks. Conversely, women differ in what they target as the central to social violence today and in their views on the primary cause of exploitation, isolation, and reduction of women in society. Mills (2005: 3) states feminism has three waves:

- First Wave : the early-century activism that led to women being liberated. It describes a woman's struggle for politics rights. It began in the nineteenth and early twentieth centuries when women were granted these rights.

- Second Wave : As state by Green and LeBihan (2001: 6), The period of extraordinary change in feminist influence that happened in the late 1960s that extended feminism's 
goals to equality elsewhere, its factors such as in education, the workplace and at home.

- Third Wave : Third and present of feminism wave goes further in terms of criticizing previous waves and celebrating that internal differences even among women are caused by factors such as race, class, nationality, and religion, and should not be overlooked.

\subsection{Language and Gender}

Language and gender have certain relationships which has been the topic of great interest for several decades. It's important to look at the relationship between gender and language in detail. Green and LeBihan (2001: 32) states that language is seen as something that people have learn the basic system, or languege as what Saussure called it is definitely respect to gender-neutral. But this in itself masks a fundamental of androcentrism: the belief that man is at the center of things. Gender is a complex term that can be observed in many ways. Coates (2013: 4) defines gender as a term used to describe social categories based on it sex. (Graddol and Swann (1989: 7) added, a general understanding of this word is seen as referring to "a social difference between male and female". In order to avoid confusion on the meaning and the use of these two terms which are similar. Sex refers to 'a biological difference' which reveals that a man and a woman are different from each other because of their biological category. Sexism is said to be a problem initially raised by feminists and not by linguists since feminists see that language is always biased towards women and that men seem to be the norm, Graddol and Swann (1989: 99).

Herman (1995) shows that sexism and hatred of women are too divisive in society, but nonetheless the wording is highest. He presents several aspects of linguistic sexism used against women, listed below:

- The use of pronouns in educational material tends to be preferred by men, apart from the generic use of 'he' which is most evident outside of linguistics.

- The publishing house editorial habit eliminates women's identity when they refer to women, more to their husbands.

- The use of address forms and naming practices, such as '-ette' for a woman's personal name.

- Women's titles such as 'Miss' and 'Mrs' distinguish women based on their sexual availability because there is no appropriate contrast for men.

- The practice of referring to women as belonging to men is more prevalent in society than vice versa - thus, women are more often referred to as 'John's girlfriend', 'Bill's wife', etc.

- Terms intended for Men or Boys with the connotation of women also experience the same ranking downgrade, as in 'sissy', 'effeminate', etc., while the masculine connotation attached to the term girl like 'tomboy' seems to be more beneficial. (Interestingly enough, the same phenomenon applies to other languages, including 
Arabic, where attaching feminine qualities to men is used to show contempt, while placing masculine attributes on women increases it.)

Herman (1995: 248) shows that modern language research in relation to cognitive skills and brain function, which tries to identify whether there are biological differences, tends to benefit women. However, Herman argues, this study is controversial because of the political political, social and ethical consequences of beliefs that distinguish between groups on a biological basis.

\subsection{Stylistics}

Etymologically, stylistics comes from the word stilus (Latin) which means a sharp pointed tool for writing. The skill to use this device is called stilus exercitotus or style practitioner. It develops new meaning by still maintain its roots. Then developed several connotations of sharp points that have to do with scratching, stabbing and even hurting. In literature, scratching means touching the reader's feelings to improve certain effect. When the word stilus brought to England, it became 'style'. Style refers to the particular way in which something is done (Oxford Dictionary, 2000). Stylistics definition has evolved over time because, literature, culture, and conventions in society also continue to develop. That the simplest definition is the study of style. Historically, the term style of language emerged after the rise of the term rhetoric. Rhetoric refers to the art of using words impressively in speech or writing (Oxford Dictionary). Rhetoric is often used by those who are want to achieve their goals to influence the audience. To achieve the goal, they need this type of material to make an impressive speech. That the ingredients here are due to a special way of framing and expressing ideas.

\subsection{Feminist Stylistics}

Feminist stylistics introduce readers for various problems and skills in text analysis to answer the questions asked especially in a feminist perspective. As a feminist linguist, Mills has obtained recognition, one of her famous work is Feminist Stylistics (2005). She was given a clearer one the definition of Feminist Stylistics as a form of politically motivated language style the aim is to develop awareness about the way gender is handled in texts, Mills (2005: 165). It is a field of study that includes feminism and linguistics.

\subsection{The Adopted Model}

This study aims to find out how female's sentences are presented in the analysis at individual word levels, phrases/ sentences level and discourse level. Feminist stylistics itself is the latest development of stylistics includes:

- Analysis at the Word Level: Mills (2005: 84) states that language can produce our perception of gender roles and sexism or it's the consequences of sexism in society are contradictory issues. On the other hand, this is the undeniable notion of linguistic 
determinism shows that language produces us world impression. This is the reason why feminists need language to reform, first on words.

- Analysis at the Phrase and Sentence Level: The presentation that the researcher wishes to demonstrate in a narrative with an honest recognition of a female person about her internal thoughts to the reader. The narrator, who is also a character in the text, freely lets out her thoughts and feelings as she describes events that happen at certain times of her life. Generally, some parts of this text are gender-specific. Some gender-specific statements in a way that defines the characteristics of a man or woman, or only talks about men or women.

- Analysis at the Discourse Level: There are a number of gender assumptions that require the reader's text. In terms of character, there are a number of texts that use stereotypical knowledge when presenting information about characters, male or female. The way women and men are represented is different. For example, in the novel The Sun and Her Flowers, which contains references to male and female characters that have been introduced to the reader differently. The main difference that the text emphasizes is not on the physical characteristics of women and men but on their attitudes, values, priorities and choices in their lives. Also, this book shows how it is to be a woman of struggle.

\section{Research Method}

This research adopted qualitative method based on Ravitch et. al. (2015) to focus on the developing of the conceptual, theoretical, and methodological knowledge needed to engage in rigorous and valid research. The qualitative descriptive proposed by Creswell (2009) was applied as data analysis design. The data collection was carried out in several stages, namely perusing and understanding the collection of poems entitled The Sun and Her Flowers, finding/ collecting the required data, and writing the significant points related to the data needed for the analysis. The data were analyzed in several steps, namely identified, categorized/ classified, described, interpreted and analyzed by using the feminist linguistic stylistics approach. Then the conclusions are summarized based on the findings of the analyzed data.

\section{Discussion}

\subsection{Stylistics Analysis}

The subject of The Sun and Her Flowers is based on love and loss, trauma and abuse, healing, femininity and the body. Specific themes of female infancy, immigration and borders will fulfill Kaur's mission: equality and love for all genders, ethnicities and backgrounds. Kaur's thought process at the break of a difficult relationship. She pointed out, "We are all our own suns and flowers are the experiences and the people we got through in our entire lifetime, so the sun and her flowers.". The style identical to "milk and honey" by reflecting her culture. This is done by introducing the Gurmukhi script, using only lowercase letters. In particular, it avoids traditional punctuation to power each line. There is a mixture of short poems with longer recitations when reciting issues such 
A Feminist Stylistics Analysis in Rupi Kaur's The Sun and Her Flowers, Saskia Febiola Siregar, Eddy Setia, Siamir Marulafau

as her parents broken English and her beauty or self-loathing after sexual abuse. Her poems often lack specific titles and boundaries; they can be read as lines or separately. The Sun and Her Flowers contemplated as a collection which describing unhealthy relationships and how poisonous love destroys our view of the world. Because of the recent climate, Kaur was drawn to write about the political implications of diaspora and immigration. There is an obvious shift from the retelling of love and healing poems seen in "milk and honey" to a disturbing narrative of racial issues.

\subsection{Analysis at the Word Level}

Analysis at this level focuses on gender bias that can be seen in use of individual words or lexical items. This part of the analysis focuses on the presentation of a few words indicates the specific gender that the resaercher found in the book The Sun and Her Flowers as follows on the table below.

Table 4.1.1a The Words used Specific Gender in The Sun and Her Flowers

\begin{tabular}{|c|c|c|}
\hline \multirow{2}{*}{$\begin{array}{c}\text { Specific } \\
\text { Gender } \\
\text { (Word Level) } \\
\end{array}$} & \multicolumn{2}{|c|}{ The book "The Sun and Her Flowers" } \\
\hline & Male & Female \\
\hline 1 & he $(p, 31)$ & women $(\mathrm{p}, 28)$ \\
\hline 2 & $\operatorname{him}(\mathrm{p}, 31)$ & theraphist $(\mathrm{p}, 30)$ \\
\hline 3 & you $(\mathrm{p}, 36)$ & beautiful $(p, 30)$ \\
\hline 4 & dads $(p, 68)$ & her $(\mathrm{p}, 31)$ \\
\hline 5 & men $(\mathrm{p}, 70)$ & she $(p, 40)$ \\
\hline 6 & doctors $(\mathrm{p}, 70)$ & $\mathrm{i}(\mathrm{p}, 60)$ \\
\hline 7 & $\operatorname{manhood}(\mathrm{p}, 71)$ & necklace $(\mathrm{p}, 68)$ \\
\hline 8 & father $(p, 88)$ & earrings $(p, 68)$ \\
\hline 9 & ugly $(\mathrm{p}, 88)$ & lipstick $(\mathrm{p}, 68)$ \\
\hline 10 & boys $(\mathrm{p}, 84)$ & mother $(\mathrm{p}, 69)$ \\
\hline 11 & devil $(\mathrm{p}, 102)$ & breasts $(\mathrm{p}, 69)$ \\
\hline 12 & uncles $(\mathrm{p}, 102)$ & $\operatorname{girl}(\mathrm{p}, 76)$ \\
\hline 13 & brother $(\mathrm{p}, 124)$ & auntie $(\mathrm{p}, 80)$ \\
\hline 14 & husbands (p, 133) & girlhood $(p, 80)$ \\
\hline 15 & husband $(\mathrm{p}, 134)$ & girls $(\mathrm{p}, 80)$ \\
\hline 16 & his $(p, 140)$ & auntie $(\mathrm{p}, 80)$ \\
\hline 17 & $\operatorname{man}(p, 141)$ & pretty $(\mathrm{p}, 84)$ \\
\hline 18 & boy $(p, 145)$ & $\operatorname{girl}(p, 76)$ \\
\hline 12 & sons $(\mathrm{p}, 145)$ & theirs $(\mathrm{p}, 78)$ \\
\hline 13 & $\operatorname{man}(p, 149)$ & girlhood $(p, 80)$ \\
\hline 14 & papa (p, 149) & girls $(\mathrm{p}, 80)$ \\
\hline 15 & guy $(p, 166)$ & pretty $(\mathrm{p}, 84)$ \\
\hline 16 & elder $(p, 218)$ & lasers $(p, 84)$ \\
\hline 17 & & facials $(\mathrm{p}, 84)$ \\
\hline 18 & & beauty $(\mathrm{p}, 84)$ \\
\hline
\end{tabular}




\begin{tabular}{|c|c|}
\hline 19 & boobs $(p, 94)$ \\
\hline 20 & lady $(\mathrm{p}, 95)$ \\
\hline 21 & womanhood (p, 95) \\
\hline 22 & slut $(p, 95)$ \\
\hline 23 & virgin $(p, 95)$ \\
\hline 24 & naive $(\mathrm{p}, 110)$ \\
\hline 25 & abortion (p, 133) \\
\hline 26 & daughter (p, 142) \\
\hline 27 & dress $(\mathrm{p}, 143)$ \\
\hline 28 & daughter-in-law $(\mathrm{p}, 144)$ \\
\hline 29 & baby $(\mathrm{p}, 144)$ \\
\hline 30 & wife $(p, 144)$ \\
\hline 31 & aunties $(\mathrm{p}, 145)$ \\
\hline 32 & mumma (p, 145) \\
\hline 33 & pregnancy $(\mathrm{p}, 145)$ \\
\hline 34 & female $(p, 145)$ \\
\hline 35 & tender $(\mathrm{p}, 151)$ \\
\hline 36 & make up (p, 167) \\
\hline 37 & witch $(\mathrm{p}, 198)$ \\
\hline 38 & whore $(p, 198)$ \\
\hline 39 & bride $(\mathrm{p}, 214)$ \\
\hline 40 & child (p, 218) \\
\hline 41 & needy $(p, 221)$ \\
\hline 42 & sister $(p, 232)$ \\
\hline 43 & woman $(\mathrm{p}, 42)$ \\
\hline
\end{tabular}

After presenting the words used specifically for gender above, we can see that gender specific terms are mostly used to refer primarily to female gender. In addition, this study will further investigate the generic pronous. Gender-specific pronouns are often used as a sexist way to refer to people who work stereotypically in a male and female role. The generic pronunciation 'he' is used to describe details male characters in books. Rupi Kaur wrote the generic pronoun in the beginning of the chapter 'wilting', him, he, his, you... specifically state to the boyfriend although the word "boyfriend" never mentioned clearly.

"he took and he took" (Kaur, 2017: 31)

"and i lost myself to him" (Kaur, 2017: 31)

"i could be anything in the world bu i wanted to be his" (Kaur, 2017: 26)

"i envy the winds who still witness you" (Kaur, 2017: 25)

On the next chapter 'falling', the generic pronouns mentioned 'men' in 'where panic attacks turn men into doctors to keep me calm" also follows after male specific characters which is, 'doctors' $(\mathrm{p}, 70)$. There is a perception here that all doctors are men. However, generic pronouns 'he' here usually refers to men in general. Certain non-sex 
pronouns, such as 'he, 'she' or 'they' are preferred, unless the speaker wants to take the risk of being seen align herself with stereotypical ideas about the roles of men and women.

More than that, generic pronouns focus on language sexist in which presents experiences oriented to men as generic or as the norm. The word "devil" (p, 102) is used to refer to the activity of the male main character in the book The Sun and Her Flowers follows with the word 'uncles' ( $p, 102)$.

"somewhere along the way

i lost the self-love and became my greatest enemy $i$ thought i'd seen the devil before in the uncles who touched us as children" (Kaur, 2017: 102)

The uncomfortable truth about this problem is that uncles, brothers, cousins and other relatives are often the main perpetrators of child abuse in a society, so we assumed that this term is actually only used referred to men.

Table 4.1.1b Generic Pronouns in The Sun and Her Flowers

\begin{tabular}{|c|c|c|}
\hline No. & Generic Nouns & Male or Female \\
\hline $\begin{array}{l}1 . \\
2 . \\
3 . \\
4 . \\
5 . \\
6 . \\
7 . \\
8 . \\
9 . \\
10 . \\
11 . \\
12 .\end{array}$ & $\begin{array}{l}\text { we }(\mathrm{p}, 32) \\
\text { lovers }(\mathrm{p}, 45) \\
\text { us }(\mathrm{p}, 46) \\
\text { they }(\mathrm{p}, 51) \\
\text { friends }(\mathrm{p}, 50) \\
\text { human }(\mathrm{p}, 60) \\
\text { monsters }(\mathrm{p}, 71) \\
\text { fighters }(\mathrm{p}, 71) \\
\text { beast }(\mathrm{p}, 76) \\
\text { friend }(\mathrm{p}, 80) \\
\text { adult }(\mathrm{p}, 90) \\
\text { child }(\mathrm{p}, 90)\end{array}$ & $\begin{array}{l}\text { refers to everyone but most of the talk about these } \\
\text { two characters: herself (the author) and her } \\
\text { boyfriend. }\end{array}$ \\
\hline $\begin{array}{l}13 . \\
14 . \\
15 . \\
16 . \\
17 . \\
18 .\end{array}$ & $\begin{array}{l}\text { designer }(\mathrm{p}, 134) \\
\text { immigrant }(\mathrm{p}, 138) \\
\text { lover }(\mathrm{p}, 70) \\
\text { someone }(\mathrm{p}, 101) \\
\text { children }(\mathrm{p}, 129) \\
\text { family }(\mathrm{p}, 133)\end{array}$ & $\begin{array}{l}\text { refers to everyone but mostly about the male- } \\
\text { character or the boyfriend. } \\
\text { refers to her sisters, her brother and herself (the } \\
\text { author). } \\
\text { refers to both grandfather and grandmother and their } \\
\text { children from the side of the author's father. }\end{array}$ \\
\hline $\begin{array}{l}19 . \\
20 . \\
21 . \\
22 . \\
23 . \\
24 .\end{array}$ & $\begin{array}{l}\text { magician }(\mathrm{p}, 135) \\
\text { hero }(\mathrm{p}, 135) \\
\text { heroes }(\mathrm{p}, 135) \\
\text { god }(\mathrm{p}, 135) \\
\text { godds }(\mathrm{p}, 135) \\
\text { parents }(\mathrm{p}, 138)\end{array}$ & refers to both mother and father of the author's. \\
\hline
\end{tabular}

In this case, back on the previous book of Rupi Kaur's Milk and Honey, she avoids stereotyping and humiliating the body at the same time in these lines. She has struggled whether to shave her hair that hasn't been shaved yet because she doesn't want to do it but she is being bullied at work by some "mean" girls. 
"my girlhood was too much hair

thin limbs coated in velvet

it was neighborhood tradition

for the other young girls and $\mathrm{i}$

to frequent basement salons on a weekly basis" (Kaur, 2017: 80)

At this present, hairless arms and legs are considered the 'sexy' norm, which serves as a status symbol of the community you are from. Having hair on your arms and legs is seen as somewhat 'dirty' and adhering to having to take off body hair is a 'manicured' sign. Just like other country include India, have fully bought the seemingly inseparable link between the notion of gender about hairlessness and femininity. In this book, the first person narrator is a woman, namely, Rupi Kaur herself. As for the main female character, Rupi Kaur does describe her physical characteristics details.

"who were my mother's age

had my mother's skin

but looked nothing like my simple mother

they had brown skin with

yellow hair meant for white skin

streaks like zebras

slits for eyebrows

i looked at my own caterpillars with shame

and dreamt mine would be that thin" (Kaur, 2017: 80)

There is no naming the characters in The Sun and Her Flowers. The other way to identify inequalities in gender-specific terms in English is to look at the type of words which describe the terms male and female. The order in which the term pair appears is another dimension of the unequal status of the terms masculine and feminine. The fact that many binary terms are usually preceded by the term male prioritizing male, because the elements that come first in English are generally considered the most important in terms of information processing. The following table shows examples of feminine terms that conventionally take precedencefrom masculine that found in the book The Sun and Her Flowers.

Table 4.1.1c The Masculine and Feminine Terms in The Sun and Her Flowers

\begin{tabular}{|c|c|}
\hline Feminine & Masculine \\
\hline mother $(\mathrm{p}, 139)$ & father $(\mathrm{p}, 139)$ \\
\hline hers $(\mathrm{p}, 140)$ & his $(\mathrm{p}, 140)$ \\
\hline she $(\mathrm{p}, 140)$ & he $(\mathrm{p}, 140)$ \\
\hline sisters $(\mathrm{p}, 5)$ & brothers $(\mathrm{p}, 5)$ \\
\hline women $(\mathrm{p}, 95)$ & men $(\mathrm{p}, 95)$ \\
\hline
\end{tabular}

There are other words that refer to only women found in the novel, such as "pretty" (p. 84) and beautiful (p, 30), which do not seem to have a male identical and have no a degrading effect simply because they are commonly used to refer to women. There are also words that refer to women as lowly human, such as the words "witch, whore (p, 198)". In this book, the author also uses the term to describe men or women showing sexual connotations. For example, the term "boobs" is found in a scene where Rupi Kaur tells about the habits of her childhood friend which are boys, when she was twelve, as mentioned in the following quote below. 
A Feminist Stylistics Analysis in Rupi Kaur's The Sun and Her Flowers, Saskia Febiola Siregar, Eddy Setia, Siamir Marulafau

\author{
"boobs \\ he said \\ let me see yours \\ there is nothing worth seeing here but guilt and shame \\ $\mathrm{i}$ try to rot into the earth below my feet \\ but $i$ am still standing one foot across \\ from his hooked fingers \\ and when he charges to feast on my half moons \\ $\mathrm{i}$ bite into his forearm and decide $\mathrm{i}$ hate this body \\ i must have done something terrible to deserve it" (Kaur, 2017: 94)
}

In addition, there are some positive and negative words used to describe the characters in the story and this term has positive and negative connotations. Rupi Kaur describing herself; for the examples, "too much hair" (p, 80), "ugly" (p, 88) and "beautiful" (p, 84).

Table 4.1.1d Positive and Negative Connotation in The Sun and Her Flowers

\begin{tabular}{|c|c|c|}
\hline \multirow{2}{*}{$\begin{array}{l}\text { The terms used to describe } \\
\text { males or females with } \\
\text { positive or negative } \\
\text { connotations. }\end{array}$} & Males & Females \\
\hline & $\begin{array}{l}\text { The man of the author's } \\
\text { 'old love' is described both } \\
\text { negative and positive: } \\
\text { 1. hair-changed (p, 24) } \\
\text { 2. break women in like } \\
\text { shoes ( }, 28 \text { ) } \\
\text { 3. five foot eleven } \\
\text { medium-sized brown- } \\
\text { skinned guy (p, 30) } \\
\text { 4. likes eating frozen } \\
\text { pizza for breakfast (p, } \\
\text { 30) } \\
\text { 5. long for someone else } \\
\text { (p, 39) } \\
\text { 6. missing limb (p, 44) } \\
\text { 7. the love that left } \\
\text { behind (p, 45) } \\
\text { 8. baby (p,47) } \\
\text { 9. sugar baby (p, 47) } \\
\text { 10. sweet baby (p, 47) } \\
\text { 11. built a cage to keep her } \\
\text { in (p, 198) } \\
\text { 12. set fire to her book (p, } \\
\text { 198) } \\
\text { 13. his tired eyes bertrayed } \\
\text { him (p, 198) } \\
\text { The man of the author's } \\
\text { 'new love' is described } \\
\text { mostly in positive: } \\
\text { 1. sweet (p, 158) }\end{array}$ & $\begin{array}{l}\text { Rupi Kaur is described both } \\
\text { positive and negative such as: } \\
\text { 1. so striking ( }, 40) \\
\text { 2. the greatest lost }(\mathrm{p}, 48) \\
\text { 3. warmest place }(\mathrm{p}, 75) \\
\text { 4. grand failure }(\mathrm{p}, 78) \\
\text { 5. premature double chin (p, } \\
\text { 88) } \\
\text { 6. too much hair (p, 80) } \\
\text { 7. thin limbs coated in } \\
\text { velvet (p, 88) } \\
\text { 8. beautiful (p, 84) } \\
\text { 9. thin (p, 88) } \\
\text { 10. ugly (p, 88) } \\
\text { 11. shoulders like candle wax } \\
\text { (p, 88) } \\
\text { 12. the bags under eyes (p, } \\
\text { 88) } \\
\text { 13. act like a lady (p, 95 } \\
\text { 14. worn (p, 96) } \\
\text { 15. lost the self-love (p, 102) } \\
\text { 16. not good enough (p, 105) } \\
\text { 17. the offspring-voice (p, } \\
\text { 139) } \\
\text { 18. switchboard (p, 165) } \\
\text { 19. running in circles (p, } \\
\text { 168) } \\
\text { 20. made of water (p, 179) } \\
\text { 21. emotional (p, 179) } \\
\text { 22. still water (p, 179) }\end{array}$ \\
\hline
\end{tabular}




\begin{tabular}{|c|c|c|}
\hline & $\begin{array}{l}\text { 2. concept of passion is } \\
\text { eye contact }(p, 158) \\
\text { 3. the circuits }(p, 165) \\
\text { 4. looked like a regular } \\
\text { guy with regular clothes } \\
\text { and regular coffee }(p, \\
\text { 166) } \\
\text { 5. the moon }(p, 179) \\
\text { 6. have a honeycomb for a } \\
\text { heart }(p, 191)\end{array}$ & 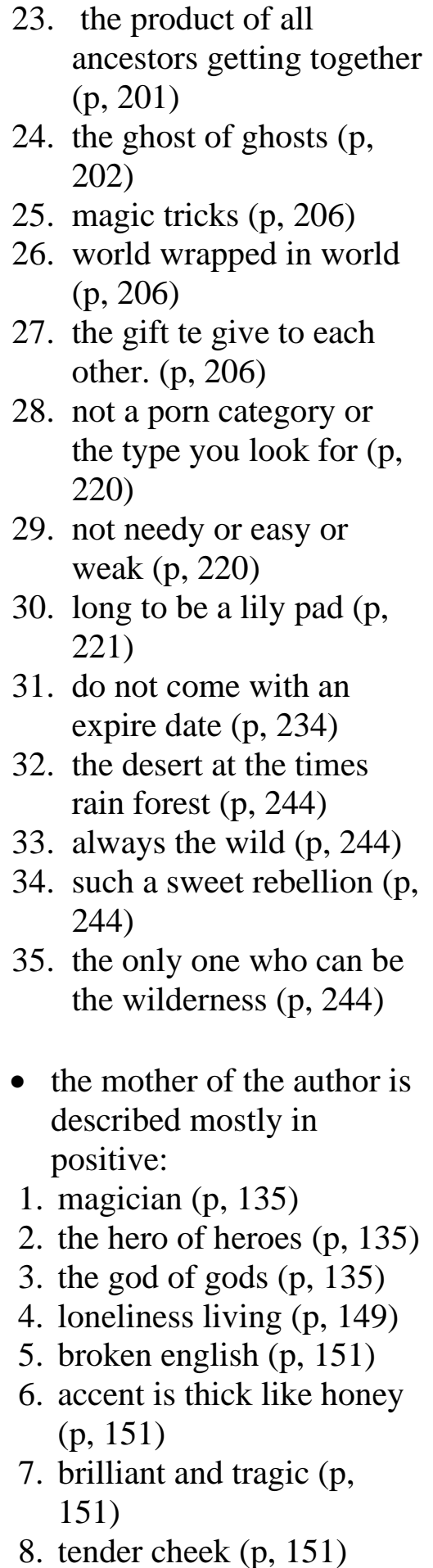 \\
\hline
\end{tabular}

\subsection{Analysis at the Phrase and Sentence Level}

It is a common contemporary linguistic belief that words must be analyzed "in relation to their context" (Mills, 2005: 98) because the meaning is not contained only in the words themselves. This explanation shows that the text must also analyzed at the phrase or sentence level. Mills declares certain criteria for check the text at the phrase level based on previous research. Analysts should be careful with phrases that are ready to be used, assumptions and conclusions, metaphors, jokes or humorous choices, and 
transitivity when examining phrases that might decompose significantly gender-biased features.

\section{Ready-Made Phrase}

Mills (2005: 98) claims, "there are...phrase which are preconstructed and which convey sexist meanings". This study follows previous research that has been tried to investigate texts that contain proverbs and also establish phrases that have found that exist indeed, the underlying message in this form discriminates against women. Mills cites the phrase as an example based on previous research by others scholars who show various ways in which a woman can be discriminated against in certain text, like the phrase 'A woman's work is never done'. This phrase can be used to suggest that the specificity of her difficulty working conditions are not as important as the general 'facts' that women have always have too much work to do. A further proverb, 'The way to a man's heart is through his stomach', naturalize a series of different ideological messages, Mills (2005: 99). This saying that for a woman to attract a man, she must do well on cooking for him. This seems to indicate that a women need to be pleasant and satisfying men. bellow:

For example, in one description Rupi Kaur described her physical appearance as

"my girlhood was too much hair

thin limbs coated in velvet" (Kaur, 2017: 88)

These sentences below talk about the changes in Kaur's body, as reflected in her body parts. She describes her transformation through childhood to puberty. She felt the puberty at twelve years old. Most girls get growth spurts early in their puberty. Increased body fat is also a normal part of the diet. The several sentences indicate that the text in the book has a specific gender. Other texts that specifically mention Kaur's female character, in which she had sexually harassed the boys from her childhood memories.

\section{Presupposition and Inference}

The opinion of this section is that there is a background pattern of knowledge which is assumed when the text addresses a female audience or when it is a matter of gender discussed. As pragmatic theorists, Brown and Yule, emphasized the knowledge of a background is very important in decoding phrases or sentences. In the cases, background knowledge must involve gender assumptions, stereotypes, and ideology that is present in the community. For example, the title of the question advertisement for the Surgical Advisory Service is 'Are you happy with your looks?', Mills (2005: 102). This refers to the ideological knowledge about women in assuming that their beauty is one element that always needs improvement (there is no reason why this sentence itself should assume the answer 'No' and therefore we can only place this knowledge at the ideological level).

The text presuppositions of 'Are you happy with your looks?':

$\checkmark$ that you are not happy with your appearance;

$\checkmark$ that this woman is pleased with her appearance;

$\checkmark$ that this woman had surgery.

The text inference of 'Are you happy with your looks?':

If you want to be happy with your appearance, you need surgery.

(Mills, 2005:103) 
According to Mills (2005: 104-105), this ad has shown how to interpret phrases only in their ideological context. By making explicit assumptions and the conclusion needed to make a phrase makes sense, maybe to think about the implications of what is asserted.

"i can't even let a lover in without getting sick" (Kaur, 2017: 70)

It implied as the reader needs to be aware of the stereotype of men who are close to us can also being monster or they can hurt you physically and mentally also leaves trauma to the person they've hurting.

\section{Metaphor}

As stated by Black (1962: 17) that metaphor is a tool for drawing the implications are based on the analogy of the structure felt between the two subjects belong to a different domain. As an example, 'the man is a wolf' it can be interpreted as referring to male and female sexuality. The statement can be used to refer people who are free to choose, for a metaphorical level, seeing women being hunted in the same way as wolves hunt on their prey, Mills (2005: 105).

Metaphor finally appears at the phrase level in the very conservative way to reinforce stereotypical knowledge. Metaphors can influence us to think about certain situations in particularly the way it was stereotyped.

all the different parts in me

turned the lights off

shut the blinds

locked the doors while $i$ hid at the back of some

upstairs closet of my mind as

someone broke the windows - you

kicked the front door in-you

took everything

and then someone took me

—it was you." (Kaur, 2017: 69)

"Home" is how Kaur describes her body. When Kaur is raped in a "home", she conceptualizes her rapist as "smashing the window" and "kicking the front door in", using the this home-body metaphor to express the traumatic experience of her body.

\section{Jokes and Humour}

Mills (2005: 106) states, just because sexism might be disguised under the cover of humor, readers can unwittingly participate in perpetuation sexism is embedded in the text when he laughs at the joke. In this case, joke is considered dangerous not only because they reflect gender bias in society, but are also designed so that neither the reader nor the human listener to compete but take lightly only. Many of these jokes involve double entenders and most of the topics used are sexually molested and supposedly sexually harassing women.

e.g

A: What's the difference between a Rottweiler and a woman with PMT?

B: Lipstick

(Mills, 2005: 107) 
In the example above, the situation seems to affect only women to be seen silly, by comparing women to rottweiler where same contrast is seen as the most annoying with 'lipstick'. As for the illustates:

"you must have a

honeycomb

for a heart

how else

could man

be this sweet" (Kaur, 2017: 191)

\subsection{Analysis at the Discourse Level}

In opinion of Mills (2005: 123), general theory of discourse sees content as something that makes up negotiating text and code elements and the forces outside of the affected texts both the way text is constructed and the way we describe what was written. Discourse is gender bias, and this shows that it exists actually the patterns and structures in the discourse that present gender differences. Mills called it as "gender framework".

So the analysis can still developing by exploring the discursive framework that can be detected as gender. She tried to show that seeing speech can be in the form of words and sentences related to gender ideology by examining patterns and structures in the text. Also determines how to investigate texts at the level of speech by observing in four areas of analysis that are influenced by stereotypical ideas about gender: characterization, fragmentation, focalization, and schemata.

\section{Characterization}

Mills (2005: 123) pays attention to characterization by analyzing "the way that stereotypical notions often inform the language choices which are made when describing characters in fiction...". The difference that is seen through the text to describe male and female has been analyzed to reveal stereotypical knowledge. A large number of texts refer to stereotypical knowledge when it presented information about a character, especially when this character not 'perfected' but only briefly explained.

One of a study that has been done by Batsleer (et. al) on the novels by Bagley and Lyall which shows "male characters are described in terms of their overall appearance, by using terms such as "sand coloured", "slight in build", "broad", and "stocky", Mills (2005: 124125). This study also shows that male characters are discussed in terms of their beliefs strength and whether the narrator likes it or not. Also, male characters are introduced with descriptions of their overall appearance, but female characters likely to be explained in terms of their body parts. In this case, men and women are explained differently.

Mills (2005: 124) states, "clothes are described in order to evoke a certain type of character: a leather jacket signifying toughness, and highly polished shows denoting a superficial sophistication". In addition, Mills (2005: 125) explains that female characters, their descriptions are concerned with determine the level of sexual attraction and sexual availability, and there is a concentration on sexual characteristics that should be. As the example, 'she has a nich legs' implies that the female character here is explained in relation to sexual desire from male characte saying.

Mills (2005: 129) specifies, "males are represented as having experience". Male characters are also presented in the text in connection with their work. Whereas women have jobs because of their personal qualities rather than themselves professional skills. Female characters seem to be depicted in certain stereotypes way. This has shown the fact 
that women are usually only presented as secretary or as a teacher, described as a housewife and mother, capable certain actions, such as washing dishes and caring for children.

Investigating the book, her mother describes what a "good" women should do:

"says i should sit with my legs closed

like a women oughta" (Kaur, 2017: 95)

\section{Fragmentation}

Mills (2005: 133) explaines female fragmentation is is associated with male focalisation women are represented as objects, collections of objects, for the gaze of men.

The representation of fragmented women into anatomical elements occurs far away more often than male. This is not only true pornographic material, but advertising images, romance and love poems, between other genre. Hence the technique of fragmenting the woman's body in pornography literature has been widely noted. The description of men, on the other hand, is done at the term body as a whole and not as a fragmented part. To demonstrate:

"she tells me

i must not dress with my breast hanging

said the boys will get hungry if they see fruit

says i should sit with my legs closed" (Kaur, 2017: 95)

\section{Focalization}

Mills (2005: 139) cites from previous study that focalization can be an external or internal story. External focalization is felt close to the narrator's agent and is called 'narrator-focalizer' where is the position narrator-focalizer is a 'bird view' which has omniscient access to all characters, wherever they occur in the narratives universe. On the other hand hand, internal focalizer, is applied in texts where the narrator and focalizer are located same character "but operates independently to tell the story".

In additon, Mills (2005: 143) explaines focalization concept provides a means to identify awareness through which a fictional event is presented in a text. Relevance to this field of gender analysis is that focalization has the power to manipulate sympathy of the reader through the vision presented and evaluation implicit in that representation. For the example, certain texts that have an internal focus position can attract sympathy from a man or the female audience depends on the prevailing gender ideology that the text presents or agreed on.

Mills (2005: 166) defines focalization as the process by which events in a story are related to the reader through character awareness or narrator. The passage belows as what narrator gives the conclusion:

i will not subject my self to their ideology

cause slut shaming is rape culture

virgin praising is rape culture

The details provided in the description of the elements of women's struggle are clear that women are more likely to be depicted in terms of how women should do and how 
and how they are treated if they do not comply with the 'rules' which are said to protect woman herself, while the male character is explained in their bad attitudes.

\section{Schemata}

In studying the text of schemata, the previous studies have been found states that women "portrayed as objects, usually sexual...actively working towards their own destruction", Mills (2005: 148).

Women are also often considered to have a problem and as "having problems and as writing to someone to ask for advice", Mills (2005: 153), which give a picture of a woman as someone who is dependent and needs attention. They also presented in many texts to be " victims of terrible accidents or difficult circumstances which they go on to conquer, because of their own personal strength", (Mills, 2005: 155).

However, men are found always present themselves as superior gender by displaying macho behavior, always being dominant and strong in many situations that text has given in. Mills (2005: 170) defines schemata, "a set of preconstucted narrative choices".

To demonstrates, in the book:

$i$ am not a mannequin in the window

of your favourite shop

you can't dress me up or

throw me out when i am worn

your actions are not my responsibility

you will control yourself (Kaur, 2017: 95-96)

\section{Conclusion}

Based on the data analysis and findings presented above, the following are the main points of gender-specific presentation at the level of words, phrases, sentences and discourse. At the word level, there are several terms that refer to male and female; father (for male), doctors (for males), pretty (for female), breasts (for female), naive (for females). Gender specific terms are mostly used to refer primarily to female gender. At the phrase and sentence level, several sentences indicate that the text in the book has a specific gender. For male character "the men looked at my newborn hips with salivating lips" and for female character "i felt beautiful until the age of twelve". At the discourse level, the a stark difference between men and women are that men are always depicted as those in charge of women, whereas women are always described in terms of body parts and the one who should be blame and controlled, for example; "the men will get angry and fight" (for male) "if i just "learn to act like a lady" (for female), "slut shaming" (for female), "virgin praising" (for female).

\section{References}

Abrams, M.H and Geoffrey Galt Harpham. (2009). A Glossary of Literary Terms Nine Editions. Boston: Wadsworth Cengange Learning.

Ahmad, G., M. (2017). Feminist Stylstics. Retrived from https://www.academia.edu/36654556/Feminist_Stylistics.

Black, M. (1962). Models and Metaphor:Studies in Language and Philosophy. New York: Cornell University Press.

Carter, R., \& Simpson, P. (Eds.). (1989). Language, Discourse and Literature: An Introductory Reader in Discourse Stylistics. London and New York: Routledge. 
Cameron, D. (1992). Feminism and Linguistic Theory. 2nd edition. Houndmills, Basingstoke, Hampshire: Macmillan.

Coates, J. (2013). Women, Men and Language: A Sociolinguistic Account of Gender Differences in Language. 3rd edition. London: Routledge.

Creswell, John W. (2009). Research Design: Qualitative, Quantitative, and Mixed Methods Approaches. Newbury Park: Sage Publications.

Darweesh, A., D and Ghayadh, H., H. (2016). Invertigating Feminist Tendency In Margaret Atwood's “The Handmaid's Tale” In Terms of Sara Mills's Model. A Feminist Stylistic Study. Retrived from https://www.researchgate.net/publication/314238402_INVESTIGATING_FEMI NIST_TENDENCY_IN_MARGARET_ATWOOD\%27S_THE_HANDMAID

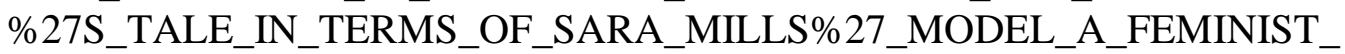
STYLISTIC_STUDY.

Ekomadyo, Agus S. (2006). Prospek Penerapan Metode Analisis Isi (Content Analysis) dalam Penelitian. Journal Itenas, No. 2 Vol. 10 Agustus 2006, p. 51-57.

Graddol, D. and Swann, J. (1989). Gender Voices. New Jersey: Wiley-Blackwell.

Gray. D. E. (2004). Doing Research in the Real Word. London: SAGE.

Green, K. and LeBihan, J. (2001). Critical Theory and Practice: A Coursbook. 2nd edition. London: Routledge.

Gibbon, M. (1999). Feminist Perspectives on Language. New York: Pearson Education.

Hama, B. S. (2017). Self-Presentation in Selected Poems of Maya Angelou A Feminist Stylistics Study. Retrived from https://www.researchgate.net/publication/331608138_Selfpresentation_in_Selected_poems_of_Maya_Angelou_A_feminist_stylistics_stud y.

Herman, V. (1995). Dramatic Discourse: Dialogue as i nteraction in plays. Routledge.

Issac, S. \&amp; Michael, W. B. (1995). Handbook in research and evaluation. San Diego, CA: EdITS.

Kaur, Rupi. (2017). The Sun and Her Flowers. UK: Simon \& Schusters.

Leech, Geoffrey. (1969). A Linguistic Guide to English Poetry. New York: Longman. Mills, S. (1995). Feminist Stylistics. London and New York: Routledge.

Mills, S. (2005). Feminist Stylistics. 2nd edition. London: Routledge.

Neuman W. Lawrence. (2000). Sosial Research Methods: Qualitative and Quantitative, pproaches. Boston: Allyn and Bacon.

Ravitch, Sharon M. (2015). Qualitative Research: Bridging the Conceptual, Theoretical, and Methodological. New York: SAGE Publications.

Riffaterre, Michael. (1971). Essais de Stylistique Structural, trans. D. Delas, Paris: Flammarion.

Vetterling-Braggin, M. (1981). Sexist Language: a Modern Philosophical Analysis. Totowa, NJ: Littlefield Adams.

Wulandari, Sari. (2018). A Feminist Stylistic Analysis in Laurie Halse Anderson's Novel Speak.

Retrived

from http://repositori.usu.ac.id/bitstream/handle/123456789/7323/140705131.pdf?seq uence $=1 \&$ is Allowed $=\mathrm{y}$.

Zeid, Mestika. (2004). Metode Penelitian Kepustakaan. Jakarta: Yayasan Obor Indonesia. 